\title{
PERAN KH. ABDUL GHOFUR DALAM PEMILIHAN UMUM TAHUN 2014 DI WILAYAH KECAMATAN PACIRAN LAMONGAN
}

\author{
Ahmad Habibur Rohman \\ Madrasah Tsanawiyah Hasyim Asy'ari Kedung Megarih Kembang Bahu Lamongan | \\ ahmad.habiburr@gmail.com
}

\begin{abstract}
This paper discusses about the role of $\mathrm{KH}$ Abdul Ghofur within the general election in 2014 in Paciran-Lamongan. $\mathrm{KH}$ Abdul Ghofur was the one behind the winning effort of Gerindra party in Paciran. From the results of recapitulation of votes of the party in the general election in 2014, the Gerindra party got a very significant vote when compared with the number of votes in the general election in 2009. On the other hands, he was also the one behind one of legislative members of DPRD of Lamongan. Based on this, it can be concluded that the political role of $\mathrm{KH}$ Abdul Ghofur can be regarded as a very successful role in the winning effort of Gerindra party in Paciran. Therefore, the political role of the clerics cannot be disputed by the political elite and society in general. They can be used as a political role of the party either religion-based party or nationalist based party or even abangan-based party.
\end{abstract}

Keywords: Role, cleric, victory, Gerindra, general election.

Abstrak: Makalah ini membahas tentang peran $\mathrm{KH}$ Abdul Ghofur dalam pemilu tahun 2014 di wilayah kecamatan Paciran Lamongan. $\mathrm{KH}$ Abdul Ghofur berperan penting dalam upaya pemenangan partai Gerindra di wilayah kecamatan Paciran. Dari hasil rekapitulasi perolehan suara partai pada pemilu tahun 2014, partai Gerindra mendapatkan suara yang sangat signifikan jika dibandingkan dengan perolehan suara partai Gerindra pada pemilu tahun 2009, selain itu beliau juga dapat menghantarkan salah satu calon anggota legislatif partai Gerindra menjadi salah satu anggota legislatif DPRD Kabupaten Lamongan. Berdasarkan hal tersebut, dapat disimpulkan bahwasannya peran politik KH Abdul Ghofur dapat dikatakan sebagai peran yang sangat berhasil dalam upaya pemenangan partai Gerindra di wilayah kecamatan Paciran. oleh karena itu peran politik seorang kyai tidak 
dapat dibantahkan oleh elit politik dan masyarakat secara umum, peran politik mereka dapat dijadikan mesin pendulang suara partai baik itu partai yang berbasis agama maupun partai yang berbasis nasionalis bahkan partai abangan.

Kata Kunci: Peran, kiai, pemenangan, Gerindra, pemilu

\section{Pendahuluan}

Dominannya peran kyai dalam sistem sosial pada masyarakat Indonesia membuat posisi para kyai sangat penting sehingga masyarakat sering menjadikan kyai sebagai rujukan dalam masalah kehidupan sehari-hari seperti urusan ibadah, pekerjaan, urusan rumah tangga bahkan urusan politik ${ }^{1}$. Di Indonesia yang kebanyakan menganut agama Islam kyai merupakan salah satu prioritas utama yang mempunyai kedudukan sangat terhormat dan berpengaruh besar pada perkembangan masyarakat tersebut. Kyai sebagai salah satu tokoh strategis dalam masyarakat karena ketokohannya sebagai figur yang mempunyai pengetahuan luas dan mendalam mengenai ajaran agama Islam².

Kharisma yang dimiliki oleh para kyai menyebabkan mereka menduduki posisi kepemimpinan dalam lingkungannya. Selain sebagai pemimpin agama dan pemimpin masyarakat desa (bahkan nasional), kiai juga memimpin pondok pesantren tempat ia tinggal, perkataan seorang kyai biasanya tidaklah dibantah, ia menjadi ikutan banyak orang, kerapkali tanpa mempersoalkan apakah dasar pendapat itu dan bagaimana nilainya ${ }^{3}$.

Sebagai elit agama, kyai mempunyai kewajiban untuk menegakkan nilai-nilai agama dengan cara amar ma'ruf nahi munkar. Pada saat yang sama, kyai sebagai salah satu sumber ajaran agama yang pandangan dan pemikirannya menjadi

\footnotetext{
' Asep Saeful Muhtadi, Komunikasi Politik Nahdlatul Ulama Pergulatan Pemikiran Politik Radikal Dan Akomodatif, (Jakarta: LP3eS, 2004), 37.

2 Ibid., 43.

3 Ainur Rofiq, "Peran Kiai dalam Perubahan Sosial Politik pada Masyarakat Sumber Anyar Kecamatan Mlanding Kabupaten Situbondo" (Skripsi--Fakultas Dakwah IAIN Sunan Ampel, Surabaya, 2006), 7.
} 
referensi. Sebagai elit sosial, kyai menjadi panutan dan sekaligus pelindung masyarakat dari tindakan kesewenang-wenangan pemerintah. Dalam kaitan kyai sebagai figur yang paling terpandang di kalangan masyarakat yang menjadikan setiap perilaku dan ucapannya diikuti oleh masyarakat.

Setidaknya ada tiga perilaku substantif seorang kyai yang menjadi acuan seorang kyai dalam kepemimpinannya, di antaranya adalah: basis masa yang merupakan pola struktural sosialnya, basis ulama' yang merepresentasikan struktur kepemimpinan kyai tersebut dan basis tradisi yang secara kultural menjadi semacam sistem budaya yang mengikat keislaman dan keilmuan yang mereka anut. Kyai dan penganutnya adalah sebuah pola relasi emosional layaknya tradisi feodal tetapi tanpa struktur dan tingkatan politis seperti tradisi dalam pemerintahan kerajaan.

Oleh karena basis masa yang dengan mudah digalang oleh seorang kyai, maka kyai dianggap sebagai ujung tombak oleh para petinggi parpol peserta pemilu, perpol berlomba-lomba mendekati dan menggalang masa untuk mendukungnya karena fatwa yang di keluarkan oleh kyai tersebut akan selalu dianut oleh setiap santri dan masyarakat umum.

Di kalangan NU, di mana kyai dan tokoh pesantren menjadi pilar kultural utamanya sehingga muncul beberapa partai politik yang masing-masing mengklaim sebagai representasi politik organisasi ini. Masing-masing juga berupaya menempatkan beberapa kyai dan tokoh pesantren sebagai motor penggerak ataupun sekedar legitimasi. Sebagai contoh, pada saat kampanye pemilu 1977, Kyai Bisyri Syamsuri dengan kapasitasnya sebagai kyai NU dan ketua Majelis Pertimbangan Partai PPP, mengeluarkan "fatwa politik", bahwa setiap muslim diharuskan memilih PPP. Sikap radikal beliau ini dalam teori politik disebut dengan Counters-Hegemoni ${ }^{4}$. Orientasi politik Nahdlatul Ulama (NU) sebagai organisasi para kyai dari kalangan Islam

\footnotetext{
${ }^{4}$ Bruinessen, Van Martin. NU Tradisi Relasi-Relasi Kuasa, (Yogyakarta: LKIS, 1994), 105.
}

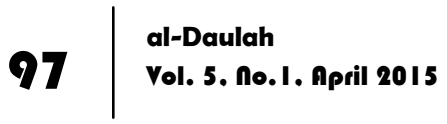


tradisionalis, termasuk dalam kelompok akomodisionis. Meski demikian, dalam berpolitik, sebagian kyai NU terkadang juga menempuh strategi politik militan, tergantung dari kondisi yang dihadapi. Namun secara umum, pandangan politik kyai dan NU lebih bersifat akomodisionis ${ }^{5}$.

Mitos ulama' harus terlibat dalam politik telah menghinggapi $\mathrm{NU}$, sehingga sejak awal mula NU sudah berurusan dengan politik, keterlibatannya dalam sidang kantoor voor inlandsche zaken di Jakarta tahun 1929 yang membahas soal perkawinan umat dan perbaikan organisasi penghulu, bahkan pada tahun 1938 dalam muktamarnya di banjarmasin NU memutuskan bahwa Indonesia adalah darul Islam (negeri muslim), dengan alasan bahwa mayoritas penduduk Indonesia adalah muslim dan Islam memiliki syariat tersendiri selain itu negara ini pernah dipimpin oleh kerajaan-kerajaan muslim.

Karir politik NU bertahan sampai jenderal Soeharto menjadi presiden 1965, posisi ulama NU sangat penting saat Achmad Syaikhu di Dewan Perwakilan Rakyat GR (DPR-GR) dan Subchan di Majelis Permusyawaratan Rakyat Sementara (MPRS), tetapi sejak tahun 1963 ulama' NU tidak lagi menduduki peran penting6.

Secara umum peran dari seorang kyai adalah sebagai penuntun dan pengarah dalam segi keilmuan agama kepada masyarakat atau umat, oleh karena perannya dalam masyarakat yang sangat aktif, ini menjadi sangat rawan dalam percaturan politik, eksistensi seorang kyai dalam memobilisasi masyarakat dalam segi keilmuan sering kali dimanfaatkan oleh partai poitik sebagai partner dalam pemenangan partainya, dengan alasan kyai sebagai elit agama dapat menjadi tolak ukur masa yang ada di sekitarnya. Beberapa dimensi keterlibatan kyai dalam politik dalam konteks sosial maupun ekonomi yang diperkirakan berpengaruh hingga mengakibatkan lahirnya variasi respon kyai

${ }^{5}$ Effendi, Bakhtiar, Islam dan Negara Transformasi Pemikiran dan Praktik Politik Islam di Indonesia, (Jakarta: Paramadina, 1998), 42.

${ }^{6}$ Zuly Qodir, Islam Syariah Vis-A-Vis Negara, (Yogyakarta: Pustaka Pelajar, 2007), 130.

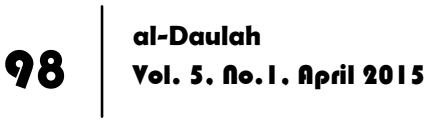


dalam politik itu sendiri, ada yang dengan tegas menyatakan tidak mau terlibat dengan politik, ada pula yang terang-terangan mendukung salah satu partai politik dengan berbagai macam alasan. Karena partisipasi lebih memberikan nuansa aktif dan dilakukan dengan kesengajaan ${ }^{7}$.

Politik yang bahasa Arabnya biasa disebut dengan istilah "Siyasah" yang berarti cerdik atau bijaksana. Bisa diartikan pula kata politik berasal dari kata "polis" yang berarti negara kota, yang jika dikaitkan maka terdapat hubungan khusus antara manusia yang hidup bersama dalam suatu negara dan dalam hubungan tersebut akan timbul suatu aturan dan kewenangan dan akhirnya mengarah pada kekuasaan. Dalam bukunya, Inu Kencana menjelaskan arti politik yang bisa disebut sebagai kebijaksanaan, kekuatan, kekuasaan, pemerintahan, konflik dan pembagian katakata yang sempurna8.

Politik dalam arti luas adalah suatu kegiatan mencari dan mempertahankan kekuasaan dalam masyarakat, oleh karena itu ilmu politik dirumuskan sebagai ilmu yang mempelajari hakikat, kedudukan dan penggunaan kekuasaan dimanapun kekuasaan itu ditentukan. Sedangkan arti kekuasaan sendiri adalah kemampuan mempengaruhi pihak lain untuk berfikir dan berperilaku sesuai dengan kehendak yang mempengaruhi. Hegemoni yang dilakukan oleh penguasa, pemimpin, Ulama' yang ada kaitannya dalam politik merupakan langkah politik yang ditempuh dan harus di ikuti oleh pengikut atau masyarakat umum dikarenakan keputusan politik merupakan keputusan yang mengikat masyarakat ${ }^{9}$.

Namun bagi dunia Islam, politik biasa digunakan sebagai suatu cara untuk mengatur ummah atau umat. Namun dari pemikir Islam itu sendiri, politik memiliki banyak pengertian yang

\footnotetext{
7 Imam Suprayogo, Kyai dan Politik Membaca Citra Politik, (Malang: UIN-Malang Press, 2007), 44.

${ }^{8}$ Inu Kencana Syafii, Ilmu Politik, (Jakarta: Rineka Cipta, 1997), 19.

${ }^{9}$ Ramlan Surbakti, Memahami Ilmu Politik, (Jakarta: PT Grasindo, 1999), 5.
}

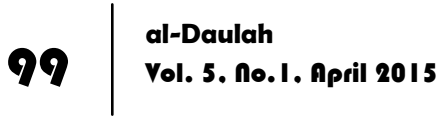


seluruhnya mengenai bagaimana cara mengatur umat. Seperti yang disampaikan oleh Ar- Raghib Al-Ashfihani, penulis kitab Mufradat Al-Qur'an menyatakan bahwa politik ada dua macam. Pertama, politik manusia untuk manusia itu sendiri, baik menyangkut kebutuhan raganya atau kebutuhan lainnya. Kedua, politik manusia terhadap pihak lain, baik kepada kerabatnya ataupun kepada masyarakat secara umum ${ }^{10}$.

Sehingga dapat disimpulkan bahwa politik merupakan kemampuan dalam mengorganisir ataupun mengatur pola interaksi sosial dalam masyarakat, termasuk mengatur hajat hidup masyarakat secara keseluruhan. Itulah mengapa salah satu cara yang paling ampuh dalam mengelola masyarakat ialah melalui politik dan manakala manusia yang dipercaya dalam mengatur kebijakan bermasyarakat dipilih melalui mekanisme politik, baik secara voting maupun secara musyawarah untuk mufakat.

Dalam pembahasan ini, penulis melakukan pola implementasi politik, yakni peran seorang ulama atau kyai dalam hal ini adalah KH Abdul Ghofur yang melakukan beberapa aksi dukungan politik terhadap salah satu partai politik peserta pemilu yakni partai Gerindra yang memanfaatkan kondisi beliau yang saat ini sebagai pemangku pondok pesantren untuk memobilisasi santri dan keluarga santri bahkan masyarakat umum untuk menjatuhkan pilihan terhadap partai tersebut. Yang menurut Nanang Tahqiq diimplementasikan kepada Amr Ma'ruf Nahi Munkar yang rinciannya meliputi kontrol terhadap masyarakat, memecahkan problematika masyarakat dan menjadi agen perubahan masyarakat. ${ }^{11}$

Bicara kepemimpinan $\mathrm{KH}$ Abdul Ghofur terkait kepemimpinannnya maka tidak lah terlepas dari yang disebut Kekuasaan walaupun tidak serta merta kekuasaan itu diartikan sebagai arti penguasa tapi dikiaskan pada seorang pemimpin umat

10 Yusuf Al- Qaradhawi, Meluruskan Dikotomi Agama dan Politik, Jakarta: Pustaka Al-Kautsar, 2008).

II Nanang Tahqiq, Politik Islam, (Jakarta: Prenada Media, 2004), 189. 
yang segala ucapan dan tingkah beliau adalah fatwa yang harus diikuti oleh umat atau santri-santrinya. biasanya merupakan gejala yang selalu ada dalam proses politik. Politik tanpa kekuasaan bagaikan agama tanpa moral karena begitu berkaitannya antara keduanya. Ada beberapa konsep yang berkaitan dengan kekuasaan yaitu :

a. Influence atau pengaruh, yaitu bagimana seseorang mampu mempengaruhi agar orang lain berubah secara sukarela.

b. Manipulasi adalah kemampuan untuk mempengaruhi orang lain namun yang dipengaurhi tidak menyadari.

c. Coersion adalah ancaman atau paksaan agar orang lain sesuai dengan kehendak yang punya kekuasaan.

d. Force yaitu tekanan fisik, seperti membatasi kebebasan. Ini biasanya dilengkapi dengan senjata, sehingga orang lain mengalami ketakutan.

Dapat juga dikembangkan dalam bentuk teori Hegemoni yang artinya adalah kekuasaan dan dominasi yang dipegang oleh satu kelompok sosial terhadap kelompok lainnya atau kyai dan masyarakat atau santrinya. ${ }^{12}$

Kecenderungan menarik dukungan kyai dan tokoh-tokoh pesantren tersebut memperlihatkan bahkan nilai politik kyai dihadapan para politisi dalam upaya mereka membangun basis dukungan ataupun sekedar legitimasi bagi kepentingan politiknya masih cukup tinggi. Tetapi hal tersebut dibantah oleh KH Abdul Ghofur selaku pendiri dan pengasuh PonPes Sunan Drajat, beliau menfatwakan kepada masyarakat umum melalui media masa radio dan majalah-majalah, beliau mengatakan bahwa kita harus mendukung siapapun yang akan menjadi calon pemimpin dengan partainya asalkan dia peduli terhadap pondok pesantren dan dengan visi misi untuk kemaslahatan masyarakat secara umum dengan cara apa yang difatwakan beliau ini adalah bertujuan untuk menggalang masa dan simpati masyarakat untuk

\footnotetext{
${ }^{12}$ Nezar Patria, Negara dan Hegemoni, (Yogyakarta: Pustaka Pelajar, 1999), 54.
}

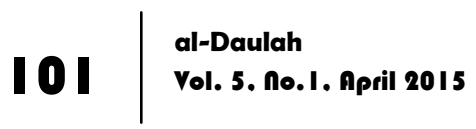


kemenangan partai Gerindra khususnya desa Banjarwati kecamatan paciran dan sekitarnya, karena beliau juga termasuk kyai yang menggagas berdirinya partai tersebut dan secara struktural beliau juga masuk dalam jajaran dewan pembina dan penasehat partai tersebut. ${ }^{13}$

Penerima gelar Doktor Honoris Causa dari America Institut Of Management Hawai Amerika Serikat ini memang sering disowani atau didekati oleh para elit politik, diantaranya adalah kedatangan calon bupati lamongan 2010 yang tidak lain adalah pernah nyantri di pondok pesantren Sunan Drajat, wakil Gubernur Jawa Timur Syaifullah Yusuf, Megawati Soekarno Putri, mantan Gubernur Jakarta Sutyoso, dan banyak lagi mentri-mentri yang juga pernah sowan kepada beliau bahkan belum lama ini Presiden Susilo Bambang Yudhoyono juga datang diakhir jabatannya sebagai presiden Indonesia sekarang, tetapi yang memang sangat rutin datang sowan adalah Prabowo Subianto yang memang telah mengakarkan partainya dipesantren tersebut sehingga partai tersebut menjadi pilihan politik beliau yang dengan tujuan sama untuk mensejahterakan masyarakat dengan pemenangan partai Gerindra. ${ }^{14}$

Syekh Yusuf Qordhowi mengatakan apabila kita melihat kepada peraturan seperti peraturan pemilu atau pemberian suara maka hal tersebut didalam pandangan islam adalah suatu persaksian untuk memilih sesuatu yang paling layak, setidaknya pandangan ini memberikan gambaran bahwa pondok pesantren Sunan Drajat khususnya KH Abdul Ghofur menginstruksikan kepada semua santri dan wali santri agar memilih partai gerindra dalam pemilu 2014 dengan alasan partai tersebut sudah dianggap menjadi partai yang paling layak untuk dipilih dengan salah satu

\footnotetext{
13 Suara Kawan, "Gerindra Restui Prabowo Maju DiPilpres 2014", http://suarakawan.com/20 I3/03/I7/gerindra-restui-prabowo-maju-di-pilpres-20 I4/, Di Unduh Pada Selasa, 13 Mei 2014 pukul 22.35

14 Mustaghfirin, "Prof $\operatorname{Dr}(\mathrm{HC}) \mathrm{KH}$ Abdul Ghofur, Sosok Dan Kiprahnya", http://tebuwung85.blogspot.com/2013/02/drhc-kh-abd-ghofur-sosok-dan-kiprahnya.html, Di Unduh Pada Selasa, 13 Mei 2014 pukul 07.II.
} 
acuannya adalah persamaan visi misi partai gerindra dan pondok pesantren Sunan Drajat yakni mengangkat masalah ekonomi kerakyatan yang selanjutnya dapat mensejahterakan masyarakat atau memberikan jaminan kepada masyarakat untuk menjadi masyarakat yang maslahah dalam urusan ekonomi dan yang lainnya.

Ini sejalan dengan pendapat Ibnu 'Aqil, dikutip dari pendapat Ibnu al-Qoyyim, bahwa Figh Siyasah adalah Perbuatan yang membawa manusia lebih dekat pada kemaslahatan (kesejahteraan) dan lebih jauh menghindari mafsadah (keburukan / kemerosotan), meskipun Rasulullah Muhammad SAW tidak menetapkannya dan wahyu tidak membimbingnya secara eksplisit fungsi dan struktur dari sistem politik.

Sosialisasi politik misalnya dapat ditemukan dalam tugas pembangunan spiritual, dengan pembangunan ini norma-norma dan ajaran agama-agama termasuk di dalamnya yang berkaitan dengan politik, dikembangkan melalui sistem pendidikan dan pengajaran sehingga masyarakat dapat memiliki persepsi dan budaya yang sama. ${ }^{15}$

Dengan begitu diharapkan masyarakat dapat melaksanakan peran masing-masing dalam kehidupan bersama dalam berbangsa dan bernegara, disisi lain pula pandangan bahwa sosialisasi politik ke masyarakat disebut pula pandangan mewariskan sistem politik yang diajarkannya sehingga melahirkan cita-cita politik yang dijanjikan Allah SWT di dalam Al Qur'an di antaranya adalah terwujudnya sebuah sistem politik, berlakunya hukum Islam dan terwujudnya ketentraman dalam kehidupan masyarakat yang biasanya digambarkan dalam ungkapan baldatun t\}hoyyibatun wa rabbun ghafur, yang memandang konsep negeri sentosa dan sejahtera ${ }^{16}$.

\footnotetext{
${ }^{15}$ Priyatno H Martokoesomo, Spiritual Thinking, (Bandung: PT.Mizan Pustaka, cet I, 2000).

${ }^{16}$ Abd Muim Salim, Fiqh Siyasah Konsepsi Kekuasaan Politik Dalam Al Qur'an, (Jakarta: PT. Raja Grafindo Persada, 1994), 298.
} 
Pesantren kedepan tampaknya berpeluang untuk terus bergulat dengan politik, oleh karena itu perlu model politik santun dengan meminjam istilah Amien Rais, yaitu berpolitik kualitas tinggi (high politics) yang memiliki tiga ciri, yaitu pertama, setiap jabatan pada hakikatnya berupa amanah dari masyarakat yang harus dipelihara sebaik-baiknya. Kekuasaan betapapun kecilnya, harus dimanfaatkan untuk membangun kesejahteraan bersama. Kedua, setiap jabatan politik mengandung dalam dirinya pertanggung jawaban, tanggung jawab dihadapan Allah SWT. Ketiga, kegiatan politik harus dikaitkan secara ketat dengan prinsip ukhuwah, yaitu persaudaraan antar sesama umat manusia, menghindari gaya politik konfrontatif yang penuh dengan konflik dan melihat pihak lain sebagai pihak yang harus dieliminasi. ${ }^{17}$

\section{Biografi KH Abdul Ghofur}

Nama lengkapnya adalah Abdul Ghofur, putra dari bapak $\mathrm{H}$. Martokan dan Ibu Hj. Kasiyami, beliau lahir didesa Banjarwati, Kecamatan Paciran pada tanggal 12 Februari 1949. Putra ketiga dari sepuluh bersaudara, ayahnya berprofesi sebagai guru ngaji dikampungnya dan bekerja sebagai petani dan pedagang kayu gamping sedangkan ibunya berprofesi sebagai penjahit baju dirumahnya. Kehidupan Abdul Ghofur di masa kecil termasuk dalam keluarga yang sangat sederhana, meskipun bukan dari keluarga orang kaya tapi perjuangan yang dilakukan untuk mendapatkan pengajaran ilmu umum maupun agama sangat luar biasa besar.

Pendidikan beliau di awali dengan sekolah di SD Negeri Desa Kranji, Kecamatan Paciran di pagi hari dan sekolah di Madrasah Ibtidaiyah Tarbiyatut Tholabah di sore hari, beliau melanjutkan sekolah tingkat menengah di Madrasah Tsanawiyah Tarbiyatut Tholabah di pagi hari dan sore hari beliau belajar kepada mbah

${ }^{17}$ Amien Rais, Hubungan Antara Politik Dan Dakwah, (Jakarta: Mujahid Press, 2004), 10.

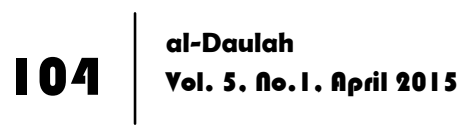


kyai Adelan. ${ }^{18}$ Selepas dari Madrasah Tsanawiyah beliau melanjutkan sekolahnya di Madrasah Aliyah Mambaul Ma'arif sambil nyantri di Pesantren Mambaul Ma'arif Denanyar Jombang dan sempat berguru langsung kepada KH. Bisri Syansuri yang merupakan salah satu seorang tokoh penting Nahdlatul Ulama'. ${ }^{19}$

Setelah nyantri di pesantren Denanyar, beliau melanjutkan ke pesantren Kramat dan pondok pesantren Sidogiri yang keduanya berada dikota Pasuruan, kemudian pada tahun 1970 beliau melanjutkan ke pesantren Sarang Jawa Tengah di bawah asuhan KH. Maimoen Zubeir dan Mbah bola yang terkenal dengan ilmu agama dan kanuragannya, setelah itu beliau melanjutkan ke pesantren Lirboyo dan Pondok pesantren Tretek yang diasuh KH. Ma'ruf Zuaeni serta pondok pesantren Roudhotul Qur'an yang di asuh KH. Asy'ari Kediri yang dari sinilah beliau banyak belajar ilmu pengobatan tradisional dan ilmu bela diri, dan pada akhirnya beliau mengakhiri perjalanan dalam mencari ilmu dipondok pesantren Salafiyah Asy-Syafi'iyah Situbondo sebelum beliau pulang dan mengamalkan ilmunya di masyarakat. ${ }^{20}$

\section{Peran Politik KH Abdul Ghofur}

Peran Ulama' dalam perpolitikan nasional memang tidak dapat diragukan lagi, sejak zaman penjajahan peran politik ulama adalah sangat besar terlebih saat ini ulama telah menjadi bagian dari peta politik di Indonesia, dengan istilah yang sedikit dimodernkan yakni "Ulama dalam pusaran politik nasional", peran Kyai Abdul Ghofur dalam perpolitikan partai Gerindra tidaklah hanya sekedar sebagai kyai panggilan partai atau kyai sebagai juru kampanye, tapi terlepas dari hal itu $\mathrm{KH}$ Abdul Ghofur adalah termasuk diantara penggagas berdirinya partai tersebut dan saat ini beliau aktif secara struktural sebagai dewan

\footnotetext{
${ }^{18}$ Sejarah Sunan Drajat Dalam Jaringan Masuknya Islam di Nusantara, (Surabaya: Tim Peneliti dan Penyusun Buku Sejarah Sunan Drajat, 1980).

19 Muhammad Rofik, "Konstruksi Sosial Dakwah Multidimensional KH. Abdul Ghofur Paciran Lamongan Jawa Timur" (Disertasi--IAIN Sunan Ampel, Surabaya, 20I I), 22.

20 Ibid.,22.
} 
penasehat pusat partai Gerindra. Peran kyai tersebut harus dilihat sebagai sesuatu yang menyatukan, yang dalam pengertian harfiahnya agama atau ulama menciptakan suatu ikatan bersama diantara anggota-anggotanya atau pengikut ulama itu sendiri baik dalam urusan ekonomi, sosial dan pilihan politiknya. ${ }^{21}$

\section{Afiliasi Politik KH Abdul Ghofur}

Peran kyai sebagaimana yang telah dituturkan oleh Yahya Aziz, sebagai pemimpin agama yang secara tradisional berasal dari keluarga yang berpengaruh terhadap santri dan masyarakat umum. Sebagai salah satu sentral pemersatu umat biasanya seorang kyai akan menjadi salah satu target partai politik untuk mendulang suara sebanyak-banyaknya, karena apa yang difatwakan oleh seorang kyai terbukti lebih mudah mengumpulkan suara daripada harus kampanye sana-sini. Banyak sekali partai politik yang menjadikan kyai sebagai ujung tombak perluasan masa dengan cara merangkul kyai dalam agenda politiknya, karena Kyai adalah salah satu aset perolehan suara yang besar karena kyai adalah termasuk dalam struktur sosial yang utama dalam masyarakat. ${ }^{22}$

Tetapi hal tersebut tidak dibenarkan oleh kyai Abdul Ghofur, apa yang dilakukannya sebagai ujung tombak partai gerindra tidaklah atas paksaan dan atas pendekatan elit politik partai Gerindra, tatapi memang sudah ada sejarah panjang antara Gerindra dengan Ponpes Sunan Drajat khususnya KH Abdul Ghofur, kyai tersebut menyatakan adanya hubungan cita-cita antara keduanya. Setidaknya banyak hal yang menjadi alasan beliau menyatakan dukungan secara terang-terangan terhadap partai Gerindra tersebut.

Berbicara mengenai arti dari Gerindra yang biasa didengar oleh masyarakat umum adalah Gerakan Indonesia Raya, tapi

21 Elisabeth K. Nottingham, Agama dan Masyarakat, (Jakarta: Raja Grafindo Persada, 2002), 34.

22 Dan Nimmo, Komunikasi Politik: Komunikator, Pesan, dan Media, (Bandung: Remadja Rosda Karya, 2000), 29. 
berbeda halnya dengan pengertian yang dikemukakan oleh beliau, beliau mengatakan bahwa Gerindra adalah Singkatan dari Gerakan Sunan Giri Sunan Drajat yang jika ditelusuri akan ditemukan alasan nama dua walisongo itu dicantumkan dalam partai tersebut, Sunan Giri adalah Wali yang terkenal pintar dalam urusan Ekonomi kerakyatan, sedangkan Sunan Drajat adalah termasuk walisongo yang terkenal ahli dalam bidang pemerintahan atau ketata negaraan. Dengan penyatuan dua tokoh dibidang perekonomian dan pemerintahan tersebut diharapkan akan melahirkan seorang pemimpin yang kelak menguasai ilmu dalam bidang pemerintahan dan perekonomian, inilah yang di ucapkan KH Abdul Ghofur yang mempunyai identitas sosial tinggi di pesantren dan masyarakat sekitar yang menurut Komarudin Hidayat dapat memainkan peran politik yang sangat kuat dimasyarakat sekitarnya. ${ }^{23}$

Setidaknya itulah doktrin atau kisah dibalik penamaan partai Gerindra dan definisi itulah yang mendarah daging dikalangan santri ponpes Sunan Drajat jika ditanyatentang afiliasi politik KH. Abdul Ghofur sebagai pengasuh pesantren tersebut.

\section{Fatwa Politik KH Abdul Ghofur}

Sosialisasi politik yang dilakukan oleh $\mathrm{KH}$ Abdul Ghofur terhadap usaha pemenangan partai Gerindra memang bervariasi, diantaranya adalah Fatwa Politik, fatwa adalah suatu pesan atau petuah yang biasanya memang dipakai dalam hierarki kyai kepada santri dan masyarakat, fatwa ini dikirimkan atau dikeluarkan oleh kyai dan diterima oleh santri dan masyarakat umum melalui banyak hal, diantaranya adalah melalui pengajian kitab yang biasa dilakukan oleh kyai dan santri. Fatwa kyai secara langsung akan membentuk sikap, persepsi dan orientasi seseorang

${ }^{23}$ Komarudin Hidayat, M. Yudhie Haryono, Manuver Politik Ulama', (Yogyakarta: Jalasutra, 2004), 24. 
yang nantinya sebagai dasar atau preferensi dalam menentukan pilihan politiknya. ${ }^{24}$

Fatwa yang disampaikan biasanya disisipkan hampir disetiap pengajian dengan landasan yang sudah ada, diantaranya adalah pertama, kesamaan Visi dan Misi yang ada dipesantren dengan salah satu visi misi yang ada pada partai Gerindra, yakni upaya pemberdayaan ekonomi kerakyatan dan pengembangan pertanian pada masyarakat kalangan menengah kebawah. Kedua, proses panjang penyeragaman tujuan partai dengan pesantren yang berujung pada perjanjian yang dilakukan oleh Prabowo terhadap Kyai Abdul Ghofur Untuk bersama-sama memajukan Indonesia menuju Fiddunya Hasanah Wa Fil Akhirati Hasanah, ketiga. Baiknya hubungan antara KH Abdul Ghofur dengan Prabowo Subianto selaku pembina Partai Gerindra dan menganggap bahwa Kyai Ghofur adalah Guru serta rujukan utama dalam bidang sosial keagamaan.

Beliau juga mengatakan bahwasanya Prabowo mempunyai jiwa dan sesuatu yang dilambangkan dengan warna merah, sedangkan Pondok Pesantren Sunan Drajat memiliki warna putih yang jika dikombinasikan akan melahirkan warna merah dan putih yang cocok untuk memimpin negara Indonesia yang saat ini membutuhkan sosok pemimpin yang seperti Prabowo, itu disampaikan pada saat puncak haul Sunan Drajat didepan ribuan santri, wali santri serta masyarakat umum, acara yang dihadiri banyak utusan koalisi gerindra itu seakan menghegemoni semua yang hadir untuk ikut serta mensukseskan pilpres 9 Juli mendatang dengan mencoblos calon presiden Prabowo Subianto.

Fatwa politik KH Abdul Ghofur secara umum kepada masyarakat luar pesantren dengan melalui berbagai media yang dimiliki oleh pondok pesantren Sunan Drajat diantaranya adalah melalui Radio "Persada FM", dan Televisi SD.TV yang menurut Brent D Ruben diartikan sebagai berikut "Ideas often seem to flow

${ }^{24}$ Khoirul Anwar, Vina Salviana, Perilaku Partai Politik "Studi Partai Politik dalam Kampanye dan Kecenderungan Pemilih Pada Pemilu 2004", (Malang: UMM Press, 2006), 24. 
from radio and print to opinion leaders and from them to the less active sections of the population", 25 serta turut terjun langsung dalam kampanye akbar di Gelora Tambaksari beberapa waktu yang lalu. KH.Abdul Ghofur seolah telah menyatu dengan Partai Gerindra.

\section{Signifikasi Perolehan Suara Partai Gerindra Tahun 2009/2014}

Signifikasi perolehan suara partai Gerindra di wilayah Kecammatan Paciran dari perolehan suara partai pada pemilu tahun 2009 dengan pemilu tahun 2014 merupakan perolehan suara yang sangat pesat dalam hitungan PPK Paciran, inilah yang membedakan antara pemilu tahun 2009 dan pemilu tahun 2014, signifikasi perolehan suara ini didasarkan pada beberapa hal, diantaranya adalah:

Pertama: pada pemilu tahun 2009 ada 2 TPS di dalam lingkungan pondok pesantren Sunan Drajat, dengan tabulasi suara mutlak milik partai Gerindra, tetapi pada pemilu tahun 2014, TPS tidak berada di dalam pondok pesatren Sunan Drajat tetapi berada di luar Pondok pesantren dengan perolehan suara yang mutlak milik partai Gerindra, ini menunjukkan bahwasannya suara partai Gerindra pada tahun 2014 sudah melegitimasi secara mutlak di desa sekitar pondok pesantren karena terhegemoni oleh peran $\mathrm{KH}$ Abdul Ghofur dalam upaya pemenangan partai Gerindra tersebut.

Kedua: dari data rekapitulasi suara pada tahun 2009, pihak PPK Kecamatan Paciran mengungkapkan bahwa suara partai Gerindra pada pemilu tahun 2009 tidak dapat diperhitungkan di wilayah kecamatan Paciran, tetapi pada tahun 2014 partai Gerindra secara spontan menjadi partai dengan perolehan suara yang sangat signifikan.

Ketiga: pada pemilu tahun 2009 partai Gerindra mencalonkan anggota legislatif di wilayah Paciran mulai dari tingkat DPRD Kabupaten, DPRD Provinsi maupun DPR RI, tetapi tidak satu pun suara partai Gerindra dapat menjadikan perolehan kursi baik

\footnotetext{
${ }^{25}$ Brent D Ruben, Communication and Human Behavior, (Prentice-Hall: New Jersey, 1992$), 29$.
}

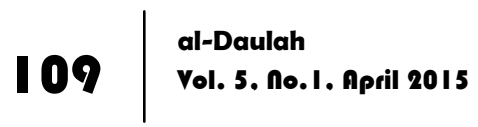


DPRD Kabupaten, DPRD Provinsi maupun DPR RI \, tetapi pada pemilu tahun 2014 partai Gerindra mendapatkan empat kursi di DPRD Kabupaten dan salah satunya berasal dari dapil di wilayah kecamatan Paciran tersebut.

Jadi sangat jelas perbedaan antara tahun 2009 dengan 2014 dari perolehan suara partai dan sistem upaya pemenangan yang dilakukan oleh KH Abdul Ghofur tersebut.

\section{Analisis terhadap Peran KH Abdul Ghofur dalam Pemenangan Partai Gerindra pada Pemilu Tahun 2014}

Di antara banyak sekali elit politik yang menggunakan namanya sebagai sebagai salah satu cara untuk memperkenalkan dirinya dalam bursa pencalonan sebagai anggota legislatif maupun calon presiden, serta menaikkan elektabilitas partai yang ditunggangi sebagai kendaraan menuju kursi di DPR, sebagai contoh pencalonan artis sebagai calon anggota legislatif dapat menaikkan elektabilitas partainya, pengusaha dengan uang yang dimiliki juga akan menaikkan perolehan suara secara baik.

Begitupun apa yang dilakukan oleh $\mathrm{KH}$ Abdul Ghofur sebagai elit pesantren, beliau memiliki kekuatan yang sangat besar yang dapat dimanfaatkan sebagai mesin pendulang suara yang sangat mudah, karena dengan adanya dalil yang menegaskan bahwasanya perintah taat pada ulama sudah sangat jelas termaktub dalam Al Qur'an surat an-Nisa ayat 59.

Yang artinya : hai orang-orang yang beriman, taatilah Allah dan Rasul (Nya), dan ulil amri diantara kamu. ${ }^{26}$ Dengan maksud bahwa ulil amri disini adalah ulama sebagai pemimpin sesuai dengan tafsiran Imam Abu Ja'far al-Thabari yang menafsirkan bahwa pendapat yang paling benar dalam hal ini adalah mereka adalah para pemimpin yang kepada Allah ketaatan dan bagi kaum

${ }^{26}$ Departemen Agama RI. A/ Qur'an dan Terjemahnya, (Surabaya: Karya Agung, 2006), I I 4. 
muslimin kebaikan dan maslahat. ${ }^{27}$ Yang berarti ulama atau kyai dalam pesantren atau masyarakat.

Tetapi berbeda dengan calon anggota legislatif yang mencalonkan diri sebagai calon anggota legislatif yang secara tidak langsung memiliki dua tujuan politis, yakni mendulang suara untuk dapat mengangkat dirinya sebagai calon anggota legislatif dan menaikkan perolehan suara partainya, dikarenakan $\mathrm{KH}$ Abdul Ghofur tidak mencalonkan diri sebagai calon anggota legislatif dari partai Gerindra tetapi beliau tetap memiliki cita-cita dan tujuan dengan afiliasi politik beliau tersebut.

Beliau mengharapkan adanya keseimbangan antara tujuan politis partai gerindra dengan tujuan umat khususnya kaum Nahdliyin dengan pola pemberdayaan dalam segala sektor khususnya pertanian dan dalam bidang kelautan atau nelayan, dengan bergabungnya beliau sebagai salah satu dewan penasehat partai Gerindra dan juga sebagai juru kampanye tim pemenangan partai gerindra beliau menggagas Indonesia kedepan harus memperbaiki dua sektor utama tersebut, hal inilah yang di anggap penting oleh $\mathrm{KH}$ Abdul Ghofur.

Dari hasil rekapitulasi perolehan suara partai Gerindra pada pemilu tahun 2009 dan 2014 di wilayah kecamatan Paciran, memang terdapat peningkatan suara partai yang sangat signifikan, ini didasarkan pada saat pemilu tahun 2009 KH Abdul Ghofur tidak melakukan peran politik seperti yang dilakukan pada pemilu tahun 2014, peningkatan suara ini jelas adalah salah satu peran politiknya, ditambah dengan berhasilnya calon anggota legislatif dari partai Gerindra untuk dapil di daerah Paciran dikursi DPRD Kabupaten Lamongan.

Sebagai contoh peran Rhoma Irama yang secara terangterangan mendukung PKB pada pemilu tahun 2014 dinyatakan sangat berhasil dengan meningkatnya suara partai kebangkitan bangsa tersebut jika di bandingkan dengan perolehan suara para

${ }^{27}$ Abu ja'far Muhammad bin Jarir al-Thabari, Jami' al-Bayan an Ta'wil Aiy al-Qur'an, (Tafsir Al Thabari Vol.VII), 947. 
pemilu tahun 2009, peran politiknya dianggap berhasil karena adanya peningkatan perolehan suara dengan berbagai cara yang salah satunya adalah mengerahkan jamaahnya untuk menjatuhkan pilihan politiknya kepada $\mathrm{PKB}$, inilah yang dapat dikatakan sebagai peran politik yang dapat mengangkat perolehan suara pemilu, begitu juga yang dilakukan oleh KH Abdul Ghofur tersebut.

KH Abdul Ghofur melakukan manuver politik dengan mendukung sepenuhnya kepada partai gerindra dalam berbagai kesempatan dengan landasan bahwa partai gerindra dan prabowo subianto telah melakukan perjanjian kepada beliau, kesamaan citacita inilah yang menjadikan mereka mereka sepakat untuk mendukung partai tersebut. KH Abdul Ghofur diharapkan dapat memberikan pandangan dan pengetahuan tentang bagaimana cara mengatur ummat dengan benar, $\mathrm{KH}$ Abdul Ghofur selalu menekankan kepada partai dan calon anggota legislatif dari partai gerindra agar selalu menjadi pemimpin yang "siap melarat kanggo kepentingan umat", dengan harapan menjadi negara yang"Gemah ripa Lok Jinawe". Dengan pola kepemimpinan yang mengutamakan kepemimpinan yang mencontoh pada kepemimpinan Rosululloh Muhammad SAW, memimpin umat dan memimpin negara secara benar dan tidak menggunakan kekerasan atau pemaksaan. Sesuai dengan hadits beliau yang bunyinya adalah:

Menceritakan kepada kami Abu Nu'aym, menceritakan kepada kami Abu al-Ashhab dari al-Hasan sesungguhnya Ubaydallah ibn Ziyad menjenguk Ma'qil ibn Yasar ketika ia sakit yang menyebabkan kematiannya, maka Ma'qil berkata kepada Ubaydallah: "Aku akan menyampaikan kepadamu sebuah hadis yang aku dengar dari Rasulullah SAW, aku mendengar Rasulullah bersabda; tiada seorang hamba yang diberi amanat rakyat oleh Allah lalu ia tidak memeliharanya dengan nasehat (baik), melainkan ia tidak akan merasakan bau (harum)nya surga. (HR. Oleh Imam Bukhari).28

\footnotetext{
${ }^{28}$ Siyasah Jinayah, Kumpulan Hadits Hukum Tata Negara, (Surabaya: t.p, 20 I 2), 29.
}

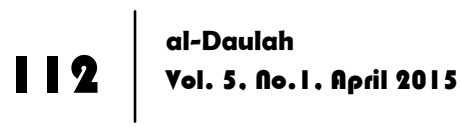




\section{Analisis Fiqh Siyasah terhadap Peran KH Abdul Ghofur dalam Pemenangan Partai Gerindra pada Pemilu Tahun 2014 di Wilayah Kecamatan Paciran}

Sosialisasi politik atau fatwa politik seorang kyai memang selayaknya juru kampanye yang memperkenalkan calon anggota legislatif atau menyuarakan nama salah satu partai politik, dalam kajian siyasah syar'iyah ini dapat dimasukkan dalam empat metode pengangkatan anggota legislatif atau kepala negara serta partai politik yang dia usung, diantara empat metode tersebut adalah kesepakatan ahlu al-hally wa al-aqdi, wasiat dari kholifah atau pemimpin sebelumnya (ikhtilaf), penggulingan kekuasaan atau kudeta (al-ghalabah) dan ajakan untuk memilih dirinya atau partainya.

Metode keempat ini yang sedang diterapkan dalam sistem perpolitikan dan kepemimpinan di Indonesia, baik oleh internal partai atau calon pemimpin maupun melalui juru kampanye seperti yang dilakukan KH Abdul Ghofur tersebut, menurut Ibnu Hazm diperbolehkan dengan catatan yang dicalonkan tersebut terpenuhi padanya syarat-syarat.

Sebagaimana yang dilakukan oleh Ali Bin Abi Tholib ketika Kholifah Utsman bin Affan terbunuh, kendati anggapan ini (ajakan untuk memilih dirinya) yang dilakukan Ali bin abi Tholib bisa saja mengarah kesana melalui indikasi yang ada namun tetap perlu ditinjau ulang karena riwayat-riwayat pada sejarang pengangkatan khulafaurrosyidin menunjukkan bahwa pada mulanya Ali bin abi Tholib keberatan menerima jabatan kholifah tersebut.

Dari Muhammad bin al-Hanafiyah, ia berkata "aku bersama ali saat utsman dikepung, tiba-tiba datang seorang laki-laki berkata "sesungguhnya Amirul mukminin baru saja terbunuh". Ali segera bangkit dan aku mencegahnya karena khawatir akan keselamatan beliau. Beliau berkata "celaka kamu ini. Lalu Ali bin Abi Tholib segera menuju kediaman Utsman dan ternyata beliau telah terbunuh, Ali bin Abi tholib beranjak pulang dan mengunci

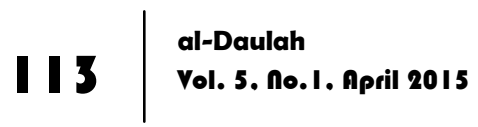


rumah, orang-orang mendatanginya sambil menggedor pintu dan berhasil masuk rumah menemui beliau. Mereka berkata "Utsman telah terbunuh sedangkan orang-orang harus tetap mempunyai kholifah, kami tidak menemukan orang yang lebih pantas darimu", Ali berkata Tidak, kalian tidak menghendaki diriku aku lebih suka menjadi wazir kalian daripada menjadi amir kalian', dan orang-orang tetap bersikukuh memaksa ali menjadi kholifah. Ali pun berkata "jika kalian tetap memaksa maka bai'atku bukan bai'at rahasia, aku akan menuju masjid, barang siapa yang ingin membaiatku maka pergilah kemasjid" dan orang-orang membai' at beliau. Dan ini bukan termasuk dalam tazkiyah al-nafs (menganggap dirinya suci). Serta ditegaskan Allah dalam Al Qur'an surat yusuf ayat 55:

"Berkata Yusuf: "Jadikanlah aku bendaharawan negara (Mesir); Sesungguhnya aku adalah orang yang pandai menjaga, lagi berpengetahuan." 29

Al-Allamah Al-Alusi menyatakan dalam tafsirnya "ayat ini merupakan dalil kebolehan seseorang memuji dirinya dengan sebenar-benarnya jika keadaan tidak dikenal, demikian pula kebolehan meminta jabatan (kekuasaan) jika memang dianggaap dirinya atau yang dicalonkannya memang sanggup bersikap adil" bahkan bisa dikatakan menjadi suatu kewajiban baginya.

Ada perbedaan maksud yang sangat mirip antara dilarangnya meminta jabatan dengan diperbolehkannya meminta jabatan dengan dasar bahwasanya jabatan itu akan datang sendiri dari Allah melalui perantara kepercayaan yang diberikan oleh masyarakat sehingga ia dipilih dan amanat diberikan kepadanya, dengan memang nyata-nyata masyarakat memilihnya dengan landasan kampanye yang dilakukan calon atau juru kampanye tersebut. Jadi perbedaannya sangat tipis jika ditelaah melalui kepercayaan yang diberikan masyarakat tersebut.

${ }^{29}$ Departemen Agama RI, A/ Qur'an, 326. 
Peran politik kyai memang sangat diperdebatkan oleh kalangan umat Islam khususnya elit kyai, tiga golongan yang mewakili polemik antara boleh dan tidaknya kyai dalam percaturan politik bahkan terlibat dalam politik praktis secara langsung, golongan pertama sangat menentang keikut sertaan pemimpin pesantren atau ulama dalam perpolitikan, golongan kedua sedikit mengakomodir kepentingan kaum muslimin dengan memperbolehkan keterlibatan kyai dalam partai politik dengan catatan harus hanya partai politik yang berbasis Islam saja, dan golongan yang ketiga memperbolehkan keikut sertaan kyai dalam berpolitik baik itu partai politik berbasis islam, partai politik nasionalis bahkan partai politik abangan atau aliran marhaenisme.

Jika dianalisis dari tiga pendapat tersebut maka secara syariah peran politik $\mathrm{KH}$ Abdul Ghofur ini tidak dapat dibenarkan dikarenakan ada dua pendapat yang saling bertolak belakang yakni golongan ulama yang membolehkan dan mengharamkan keikut sertaan kyai dalam peta politik, hanya saja pendapat yang ketiga ini dapat dikatakan mengharamkan apa yang dilakukan $\mathrm{KH}$ Abdul Ghofur, karena pendapat yang ketiga ini membolehkan kyai berpolitik tetapi hanya dalam konteks partai yang berbasis islam saja, misalnya PKB, PPP, PKS, PKNU dan lain-lain. Sedangkan partai Gerindra adalah partai yang memploklamirkan dirinya sebagai partai yang terlahir dalam aliran partai nasionalis. Jadi pendapat ulama ini cenderung mengharamkan peran $\mathrm{KH}$ Abdul Ghofur karena pendapat ada dua macam dalil yang melarangnya sedangkan yang memperbolehkannya hanya satu dalil saja.

Tetapi Syaikh Abdu Aziz bin Abdullah bin Baz mengeluarkan fatwa terhadap keterlibatan kyai dalam perpolitikan, beliau mengatakan kyai masuk dalam peta politik patai itu sangat berbahaya, tetapi jika keterlibatan kyai tersebut didasarkan pada landasan ilmu dengan tujuan menegakkan yang haq dan mengarahkan manusia kepada kebaikan serta menghambat 
kebathilan maka tidaklah apa-apa kyai terlibat didalamnya. ${ }^{30}$ Sesuai dengan apa yang disampaikan Al-Maududi yang mengatakan bahwa agama yang dianut dan dijalankan oleh kyai tidak akan terpisahkan, syariat tidak mengenal pemisahan agama dan politik, karena pemerintahan menurutnya harus didasarkan pada empat prinsip dasar yakni mengakui kedaulatan Tuhan, menerima otoritas Nabi Muhammad, memiliki status wakil Tuhan dan menerapkan musyawarah dalam setiap permasalahan yang timbul. ${ }^{31}$

\section{Penutup}

Peran politik KH Abdul Ghofur dalam upaya pemenangan salah satu partai peserta pemilu yakni partai Gerindra khususnya di pondok pesantren Sunan Drajat dan di wilayah kecamatan Paciran serta pada masyarakat umum yang mendengarkan fatwafatwa politik beliau yang secara umum melalui barbagai macam cara, diantaranya adalah diselipkan disetiap pengajian yang beliau lakukan setiap pagi yang selanjutnya disiarkan langsung melalui dua media masa yakni radio dan televisi yang dimiliki oleh pondok pesantren yang secara langsung mempengaruhi perolehan suara partai Gerindra dengan menghegemoni santri dan masyarakat secara umum, mengingat beliau adalah termasuk kyai yang sangat disegani di wilayah Paciran tersebut, terlebih beliau memiliki ribuan santri dan jama'ah. Oleh karena itu dapat pula dijadikan acuan bahwa perolehan suuara partai Gerindra pada pemilu tahun 2014 sangat signifikan jika dibandingkan dengan pemilu tahun 2009 yang suara partai Gerindra tidak sampai seperti sekarang.

Apa yang dilakukan beliau ini bukan tanpa alasan, beliau yang termasuk dalam tim pemenangan partai gerindra menginginkan kemaslahatan umat dalam berbagai bidang yang

\footnotetext{
${ }^{30}$ Rapung Samuddin, Fiqih Demokrasi, 397.

31 Munawir Sadzali, Islam dan Tata Negara: Ajaran Sejarah dan Pemikiran, (Jakarta: UI Press, 1995), 166.
} 
sudah beliau diskusikan dengan dewan penasehat partai Gerindra yang sedang mencalonkan diri menjadi calon presiden 2014 tersebut. Dalam Maqasid Syariah diisyaratkan bahwa adanya Hifdhul Umah adalah termasuk yang beliau inginkan jika partai tersebut menjadi pemenang dalam pemilu 2014 agar tercipta Fiddunya Hasanah wafil akhirati hasanah atau negara yang Baldatun thaiyabatun wa rabbun ghafur. Tetapi jika ditinjau dari perdebatan ulama mengenai boleh dan tidaknya kyai berpolitik, maka kegiatan KH Abdul Ghofur tersebut tidak dapat dibenarkan secara dalil karena dalil boleh dan tidaknya kyai berpolitik dua berbanding satu.

\section{Daftar Pustaka}

Anwar, Khoirul dan Vina Salviana. Perilaku Partai Politik "Studi Partai Politik dalam Kampanye dan Kecenderungan Pemilih Pada Pemilu 2004". Malang: UMM Press, 2006.

Bruinessen, Van Martin. NU Tradisi Relasi-Relasi Kuasa. Yogyakarta: LKIS, 1994.

Departemen Agama RI. Al Qur'an dan Terjemahnya. Surabaya: Karya Agung, 2006.

Effendi, Bakhtiar. Islam dan Negara Transformasi Pemikiran dan Praktik Politik Islam di Indonesia. Jakarta: Paramadina, 1998.

Hidayat, Komarudin dan M. Yudhie Haryono. Manuver Politik Ulama'. Yogyakarta: Jalasutra, 2004.

Martokoesomo, Priyatno H. Spiritual Thinking. Bandung: PT.Mizan Pustaka, cet 1, 2000.

Muhtadi, Asep Saeful. Komunikasi Politik Nahdlatul Ulama Pergulatan Pemikiran Politik Radikal Dan Akomodatif. Jakarta: LP3eS, 2004.

Mustaghfirin. "Prof Dr (HC) KH Abdul Ghofur, Sosok Dan Kiprahnya". http://tebuwung85.blogspot.com/2013/02/drhckh-abd-ghofur-sosok-dan-kiprahnya.html, Di Unduh Pada Selasa, 13 Mei 2014 pukul 07.11. 
Nimmo, Dan. Komunikasi Politik: Komunikator, Pesan, dan Media. Bandung: Remadja Rosda Karya, 2000.

Nottingham, Elisabeth K. Agama dan Masyarakat. Jakarta: Raja Grafindo Persada, 2002.

Patria, Nezar. Negara dan Hegemoni. Yogyakarta: Pustaka Pelajar, 1999.

PPK Kecamatan Paciran Tahun 2014

Qaradhawi (Al-), Yusuf. Meluruskan Dikotomi Agama Dan Politik. Jakarta: Pustaka Al-Kautsar, 2008.

Qodir, Zuly. Islam Syariah Vis-A-Vis Negara. Yogyakarta: Pustaka Pelajar, 2007.

Rais, Amien. Hubungan Antara Politik Dan Dakwah. Jakarta: Mujahid Press, 2004.

Rofik, Muhammad. "Konstruksi Sosial Dakwah Multidimensional KH. Abdul Ghofur Paciran Lamongan Jawa Timur". Disertasi-IAIN Sunan Ampel, Surabaya, 2011.

Rofiq, Ainur. "Peran Kiai Dalam Perubahan Sosial Politik Pada Masyarakat Sumber Anyar Kecamatan Mlanding Kabupaten Situbondo". Skripsi--Fakultas Dakwah IAIN Sunan Ampel, Surabaya, 2006.

Ruben, Brent D. Communication and Human Behavior. Prentice-Hall: New Jersey, 1992.

Sadzali, Munawir. Islam dan Tata Negara: Ajaran Sejarah dan Pemikiran. Jakarta: UI Press, 1995.

Salim, Abd Mun'im. Figh Siyasah Konsepsi Kekuasaan Politik Dalam Al Qur'an. Jakarta: PT. Raja Grafindo Persada, 1994.

Sejarah Sunan Drajat Dalam Jaringan Masuknya Islam di Nusantara. Surabaya: Tim Peneliti dan Penyusun Buku Sejarah Sunan Drajat, 1980.

Siyasah Jinayah. Kumpulan Hadits Hukum Tata Negara. Surabaya: t.p, 2012.

Suara Kawan. "Gerindra Restui Prabowo Maju DiPilpres 2014", http://suarakawan.com/2013/03/17/gerindra-restui-prabowo- 
maju-di-pilpres-2014/, Di Unduh Pada Selasa, 13 Mei 2014 pukul 22.35

Suprayogo, Imam. Kyai Dan Politik Membaca Citra Politik. Malang: UIN-Malang Press, 2007.

Surbakti, Ramlan. Memahami Ilmu Politik. Jakarta: PT Grasindo, 1999.

Syafii, Inu Kencana. Ilmu Politik. Jakarta: Rineka Cipta, 1997.

Tahqiq, Nanang. Politik Islam. Jakarta: Prenada Media, 2004.

Thabari (al-), Abu Ja'far Muhammad bin Jarir. Jami' al-Bayan an Ta'wil Aiy al-Qur'an. Tafsir Al Thabari Vol.VII. 